\title{
The Effects of Co-Enzyme Q10 and Caffeine on Morphometric Characteristics of Queen Honey Bees
}

\author{
Samet Okuyan ${ }^{1, a, *}$, Paul Cross ${ }^{2, b}$ \\ ${ }^{1}$ Honey Bee Research Institute, 52000 Ordu, Turkey \\ ${ }^{2}$ School of Natural Science, Bangor University, Bangor, UK, United Kingdom
}

*Corresponding author

A R T I C L E I N F O A B S T R A C T

\section{Research Article}

Received : 19/09/2020

Accepted : 02/01/2021

\author{
Keywords: \\ Turkey \\ Conservation \\ Morphology \\ Ecotypes \\ Breeding
}

\begin{abstract}
Honey bee queen quality is a critical factor of colony performance. Indications of such qualities can manifest themselves through morphological traits such as wet weight and thorax width. Improving such characteristics is driven in part by nutritional provision in queen-cell-builder hives. We investigated the potential to improve queen quality by adding coenzyme Q10 (endogenous antioxidant) and caffeine (central nervous system stimulator) to feeder syrup in queen-cell-builder colonies for 15 and 20 days prior to grafting, two sets of queens were reared. We recorded subsequent wet weight, body length, head width and length, thorax and wing width and length, and spermathecae diameter. The queen-cell acceptance rate was not affected by either treatment or graft period. Coenzyme Q10 increased wet weight, body and wing length in the first graft, and thorax width, wing length and spermathecae diameter in the second graft. The caffeine treatment increased head and thorax length in first graft and thorax width in the second. A mix of the two substances (coenzyme Q10 and caffeine) increased head width in the first graft and spermathecae diameter in the second graft. This study suggests that the application of coenzyme Q10 to cell-builder colonies at least 15 days prior to grafting can increase reared wet weight (the most significant quality indicator) and thorax width of queen bees.
\end{abstract}

\section{Introduction}

The agricultural growth of crops reliant on insect pollinators has led to an increasing demand for pollination services (Aizen and Harder, 2009; Aizen et al., 2019). The European honey bee (Apis mellifera) is a primary provider of such services across a number of crop systems as they ensure high-density pollination events over a limited time period (Grünewald, 2010; Klein et al., 2006). The continued provision of these services is threatened by the introduction of a range of pests and diseases (Varroa destructor, Nosema etc). To cope with such challenges, beekeepers may need to improve the quality and resilience of their queens.

The queen is the only member of a bee colony that can lay fertilized eggs and her persistence within the colony is critical for survival. Consequently, her quality is a strong determinant of colony success. For instance, $5.1 \%$ of the colonies in 27 European countries as well as Algeria, Israel and Mexico have substantial queen problems such as drone egg laying due to poor mating events (Brodschneider et al.,
2018). Indicate that queen weight is positively correlated with brood area and colony size, although internal and external factors, such as climate are also important (De Souza et al., 2013). Heavier queens have increased colony acceptance rates, higher mating ratios (the rate of onset oviposition), earlier onset oviposition, wider spermathecae, hold greater quantities of sperm in the spermathecae, and produce larger brood areas 30 days after onset of oviposition than lighter (weight) queen bees (Akyol et al., 2008).

A range of factors associated with both rearing and stress influence the eventual quality of queens and their reproductive success (Kaftanoğlu et al., 1992; Amiri et al., 2017). These include the age and origin of grafted larvae, the number of young workers (less than three weeks old), food quality and availability for the cell-builder and finisher colonies, and a sufficient supply of drones for queen mating (Morse, 1993). 
Some studies indicate supplemental feeding to queencell-builder colonies may increase queen quality (Mahbobi et al., 2012; Krol A et al., 1992). Adult worker bees that consumed coenzyme Q10 and/or caffeine lived longer, were less infested with Nosema spp, had greater protein concentrations, and increased antioxidant enzyme activity (Strachecka et al., 2014a,b). Caffeine is a chemical defense against biological stressors (Ashihara and Crozier, 2001). Strachecka et al., (2014b) reported that caffeine positively affected the protective function in bees by increasing antioxidant system activity. Coenzyme Q10 had a similar effect on adult bees as caffeine. Coenzyme Q10 intake increases antioxidant enzyme activity and protease inhibitors, augmenting a bee's capacity to resist pathogen incursion (Münch et al., 2008; Strachecka et al., 2014a). Coenzyme Q10 and caffeine intake increases protein and some antioxidant enzyme activities of bees. The protein concentration of bees considerably increases 15 days after the intake. Protein concentration in the bees peaks at the 20 days, after which it begins to decline (Strachecka et al., 2014a,b). Moreover, coenzyme Q10 is an antioxidant Bentinger et al., (2007), and is expected to affect honey bees much like other antioxidants. For example, epigallocatechin3-gallate supplementation improves the survival of honey bees, and vitamin-C supplementation increases protein content, total antioxidant status, and all the antioxidant enzyme activities (Archer et al., 2014; Łopieńska B et al., 2019). In addition, caffeine is also recognized for its antioxidant properties (Lee, 2000). This led us to hypothesize that if worker bees exhibit an improved health status following feeding on coenzyme Q10 and caffeine, they would more likely exhibit increased care for queen larvae and reared better-quality queen.

\section{Materials and Methods}

The study was conducted during June and July 2018, at the apiary of the Turkish Apiculture Research Institute (Ordu province $40^{\circ} 54^{\prime} 26^{\prime \prime}$ North longitude, $37^{\circ} 50^{\prime} 07^{\prime \prime}$ East latitude and $132 \mathrm{~m}$ altitude). Twelve nine-frame colonies of Apis mellifera caucasia were selected for the study. Fifteen days before grafting, cell-builder colonies were randomly divided into three treatment and control groups (coenzyme Q10, caffeine, caffeine + coenzyme Q10, and control). Water soluble coenzyme Q10 (2,3-dimethoxy, 5-methyl, 6decaprenyl benzoquinone) and water-soluble caffeine $\left(\mathrm{C}_{8} \mathrm{H}_{10} \mathrm{~N}_{8} \mathrm{O}_{2}\right.$ mateine/1,3,7 trimethylxanthine) were obtained from Egas (Çankaya, Ankara). Coenzyme Q 10 is an oil solvable element, and does not solve in sugar syrup. Thus, we cannot apply the oil solvable form of coenzyme Q10 to honey bees. There are some commercial forms of coenzyme Q10 powder solving in water. Water solvable coenzyme Q10 needs to be used for honey bee nutrition supplements. In some cases, 1/1 sugar water solution does not necessarily reach brix 50 , which is why firstly a $1 / 1$ sugar water solution should be prepared and its brix degree verified with a refractometer. The first group (Coenzyme Q10) was administered $200 \mathrm{mg}$ of coenzyme Q10 (Strachecka et al., $2014 a)+1$ litre of sugar syrup daily. The second group (Caffeine) were given $5 \mathrm{mg}$ caffeine (Strachecka et al., $2014 b)+1$ litre of sugar syrup daily; the third group (Mix) $200 \mathrm{mg}$ coenzyme Q10 + $5 \mathrm{mg}$ caffeine + 1 litre of sugar syrup daily and the fourth group $(\mathrm{C})$ received only 1 litre of sugar syrup daily. This process was repeated 26 days at the second grating cells were capped. The feeding schedule was maintained throughout the experiment. Queens were produced by grafting larvae into queenless cell-builder colonies, according to standard rearing practices (Laidlaw $\mathrm{H}$, 1979). All grafted larvae came from same colony including the artificially inseminated Apis mellifera caucasia queen. Queen-cells were collected from cell-builder colonies six days after the first graft and introduced to the incubator colonies. The second graft was performed using the same cell-builder colonies. We grafted 45 larvae from each cell builder colony for both first and second grafts. Consequently, 540 larvae were grafted for each graft, giving a combined total of 1080 grafted larvae. Then we randomly chose queen cells and placed into a laboratory incubator at $33^{\circ} \mathrm{C}$ three days before emergence, and we evaluate 12 queens. Therefore, 144 queen cells were taken from 12 cell builder colonies giving $\mathrm{N}=144$ for each graft round. Incubated queen-cells were regularly checked, and the parameters of newly emerged queens recorded (weight, thorax length and width, and diameter of spermathecae). We measured only right forewing width and length. A digital caliper with $0.01 \mathrm{~mm}$ sensitivity was used to measure the length of body width and lengths of the head, thorax, and wing of virgin queens. $\mathrm{CO}_{2}$ were used to anaesthetize queen bees prior to measuring. A Precisa XB 220A precision scale was used to measure queen weight. The diameter of the spermathecae was measured using an Olympus SZ61 stereomicroscope and OLYMPUS stream basic software. We did not use an excluder to prevent natural resources provision to bees in cell-builder colonies because during the experimental period, floral resource availability was poor in the province. All cell-builder colonies consumed the applied syrup throughout the experiment as its potential impact was considered marginal.

\section{Statistical Analysis}

The data were analysed using one-way ANOVA to determine the effects of coenzyme Q10, caffeine and the mix of these two substances on queen weight, length, head length and width, thorax width and length, wing length and width and spermathecae diameter. Tukey multiple comparison tests were applied to compare means and significant differences between the treatment groups, and first and second grafts. Three days after grafting, we counted the number of accepted and rejected cells. We then calculated the proportion of accepted cells (AC);

$$
\mathrm{AC}=\frac{\text { Acceptet }}{\text { Grafted }} \times 100
$$

We compared acceptance rates against graft time. $\mathrm{Chi}^{2}$ tests determined significance of differences for acceptance.

\section{Results}

Grafting acceptance rates were $81.25 \%$, and $83.68 \%$ for the first and second grafts respectively. Totally 1080 larvae were grafted, and the overall acceptance rate was $82.46 \%$. There were no significant differences between acceptance rates across groups (mean $=82.4 \%, \mathrm{n}=1080, \mathrm{P}>0.05)$ (Table 1). 
Table 1. The mean acceptance rates of larvae from first and second round grafts across all treatment groups $(\mathrm{N}=1080)$.

\begin{tabular}{l|ccr}
\hline \multirow{2}{*}{ Treatment } & 15 days pre-feed (first graft) mean (\%) & 20 days pre-feed (second graft) mean (\%) & Overall \\
\cline { 2 - 4 } & Mean & Mean & 81.54 \\
\hline Control & 79.73 & 83.36 & 82.10 \\
Coenzyme Q10 & 81.30 & 82.90 & 83.09 \\
Caffeine & 82.26 & 83.93 & 83.13 \\
Mix & 81.73 & 84.53 & 82.46 \\
Overall & 81.25 & 83.68 & \\
\hline
\end{tabular}

Table 2. Mean morphometric measurements of reared queens from first and second round grafts across all treatment groups.

\begin{tabular}{|c|c|c|c|c|c|c|}
\hline Morphometric characteristics & Graft event & Control & Coenzyme Q10 & Caffeine & Mix & $\bar{P}$ \\
\hline \multirow{3}{*}{ Weights (mg) } & First & $205.08 \pm 23.83$ & $214.48 \pm 11.45$ & $199.71 \pm 19.27$ & $194.55 \pm 15.71$ & 0.001 \\
\hline & Second & $195.21 \pm 26.31$ & $209.49 \pm 21.52$ & $190.69 \pm 22.15$ & $194.40 \pm 23.44$ & 0.002 \\
\hline & $\mathrm{P}$ & 0.178 & 0.225 & 0.03 & 0.976 & \\
\hline \multirow{3}{*}{ Length (mm) } & First & $17.65 \pm 1.03$ & $18.71 \pm 0.67$ & $17.42 \pm 0.94$ & $18.05 \pm 1.16$ & 0.001 \\
\hline & Second & $17.64 \pm 0.65$ & $18.23 \pm 0.76$ & $17.69 \pm 0.86$ & $17.59 \pm 0.98$ & 0.004 \\
\hline & $\mathrm{P}$ & 0.972 & 0.021 & 0.127 & 0.076 & \\
\hline \multirow{3}{*}{ Head Length (mm) } & First & $3.80 \pm 0.18$ & $3.58 \pm 0.27$ & $3.79 \pm 0.19$ & $3.76 \pm 0.27$ & 0.002 \\
\hline & Second & $3.71 \pm 0.12$ & $3.73 \pm 1.19$ & $3.60 \pm 0.15$ & $3.59 \pm 0.21$ & 0.001 \\
\hline & $\mathrm{P}$ & 0.055 & 0.009 & 0.001 & 0.003 & \\
\hline \multirow{3}{*}{ Head width (mm) } & First & $3.83 \pm 0.14$ & $3.74 \pm 0.15$ & $3.71 \pm 0.14$ & $3.92 \pm 0.21$ & 0.001 \\
\hline & Second & $3.88 \pm 0.15$ & $3.80 \pm 0.15$ & $3.75 \pm 0.16$ & $3.77 \pm 0.15$ & 0.015 \\
\hline & $\mathrm{P}$ & 0.257 & 0.08 & 0.132 & 0.005 & \\
\hline \multirow{3}{*}{ Thorax length (mm) } & First & $4.37 \pm 0.22$ & $4.38 \pm 0.23$ & $4.48 \pm 0.19$ & $4.33 \pm 0.21$ & 0.010 \\
\hline & Second & $4.44 \pm 0.19$ & $4.40 \pm 0.22$ & $4.43 \pm 0.19$ & $4.36 \pm 0.29$ & 0.359 \\
\hline & $\mathrm{P}$ & 0.244 & 0.655 & 0.225 & 0.656 & \\
\hline \multirow{3}{*}{ Thorax width (mm) } & First & $4.50 \pm 0.22$ & $4.65 \pm 0.20$ & $4.57 \pm 0.27$ & $4.46 \pm 0.25$ & 0.023 \\
\hline & Second & $4.65 \pm 0.14$ & $4.75 \pm 0.19$ & $4.76 \pm 0.12$ & $4.60 \pm 0.17$ & 0.001 \\
\hline & $\mathrm{P}$ & 0.005 & 0.027 & 0.001 & 0.005 & \\
\hline \multirow{3}{*}{ Wing length (mm) } & First & $10.69 \pm 0.31$ & $10.80 \pm 0.61$ & $10.60 \pm 0.26$ & $10.61 \pm 0.25$ & 0.169 \\
\hline & Second & $10.63 \pm 0.17$ & $10.79 \pm 0.20$ & $10.52 \pm 0.34$ & $10.60 \pm 0.18$ & 0.001 \\
\hline & $\mathrm{P}$ & 0.367 & 0.995 & 0.173 & 0.765 & \\
\hline \multirow{3}{*}{ Wing width (mm) } & First & $3.22 \pm 0.09$ & $3.18 \pm 0.12$ & $3.17 \pm 0.11$ & $3.10 \pm 0.32$ & 0.085 \\
\hline & Second & $3.17 \pm 0.09$ & $3.17 \pm 0.10$ & $3.14 \pm 0.14$ & $3.15 \pm 0.10$ & 0.583 \\
\hline & $\mathrm{P}$ & 0.122 & 0.902 & 0.361 & 0.765 & \\
\hline \multirow{3}{*}{ Spermathecae diameter (mm) } & First & $1.11 \pm 0.07$ & $1.13 \pm 0.10$ & $1.08 \pm 0.09$ & $1.12 \pm 0.10$ & 0.095 \\
\hline & Second & $1.14 \pm 0.06$ & $1.16 \pm 0.05$ & $1.11 \pm 0.09$ & $1.16 \pm 0.06$ & 0.001 \\
\hline & $\mathrm{P}$ & 0.188 & 0.109 & 0.124 & 0.061 & \\
\hline
\end{tabular}

All means reported \pm standard deviation. First =15 days pre-feed (first graft, $n=144$ ), Second = 20 days pre-feed (second graft, $n=144$ ).

First graft queen weights, reared with coenzyme Q10, were the heaviest across all groups (mean=214.53 mg, $\mathrm{n}=144, \mathrm{P}<0.001$ ) (Table 2). Mean queen lengths for the coenzyme Q10 treatment were statistically longer than the control, caffeine and mix group for both graft periods ( $n=144,1$ st graft mean=18.63 $\mathrm{P}<0.001,2$ nd graft 18,23 $\mathrm{mm}, \mathrm{P}<0,01)$. The first graft mean head lengths for the mix, control and caffeine groups were significantly longer than the coenzyme Q10 group $(3,76 \mathrm{~mm}, 3.80 \mathrm{~mm}, 3.79 \mathrm{~mm}$ respectively; $n=144, \mathrm{P}<0.001)$. The mean head width of the first graft mix group was $3.92 \mathrm{~mm}$, and statistically wider than first graft control, coenzyme Q10 and caffeine groups $(n=144 ; \mathrm{P}<0.001)$. The second graft mean head lengths for the caffeine and mix groups were statistically shorter $(3.60$ $\mathrm{mm}$ and $3.59 \mathrm{~mm}$ respectively; $\mathrm{n}=144, \mathrm{P}<0.001)$ than control and coenzyme Q10 (3.71 mm, $3.73 \mathrm{~mm}$ respectively) groups. The longest thorax in the first graft was found in the caffeine group (mean=4.48 mm; $n=144$, $\mathrm{P}<0.001)$. The thorax length of queens was unaffected by treatment in the second graft $(P>0.05 n=144)$. The mean thorax width of the first graft coenzyme Q10 was significantly wider than the other treatments (mean $=4.68$ $\mathrm{mm} ; \mathrm{n}=144 ; \mathrm{P}<0.01)$. In the second graft coenzyme $\mathrm{Q} 10$ and caffeine were significantly wider than both the control and mix group $(\mathrm{n}=144, \mathrm{P}<0.001)$. In second graft thorax width were significantly wider than first graft in all treatments. The mean queen wing length for the second graft coenzyme Q10 was statistically longer than the control, caffeine and mix treatments (mean $=10.79 \mathrm{~mm}$; $\mathrm{n}=144 ; \mathrm{P}<0.001$ ). Wing width was unaffected by both treatment and graft period $(\mathrm{n}=288 ; \mathrm{P}>0.05)$. The second graft mean spermathecae diameter for the coenzyme Q10 and mix groups was significantly wider than other treatments $(\mathrm{n}=144 ; \mathrm{P}<0.001)$. There was no statistically significant effect across groups between graft periods $(\mathrm{P}>0.05)$.

\section{Discussion}

The quality of queen bees is determined by the genotype of reared queens as well as environmental elements such as age of grafted larvae, number of nurse bees in cell-builder colonies, nutritional stock in cellbuilder and finisher colonies, and queens mating with 
sufficient numbers of drones (Kaftanoğlu et al., 1992; Morse, 1993). Supplemental feeding positively affected queen quality, with the mean queen weight of those reared in supplemental feed groups being $11 \%$ heavier than the control groups (Krol et al., 1992). Mahbobi et al., (2012) indicated that supplemental feeding led to increases in most morphometric measurements of reared queen bees (E.g., weight, head, thorax, wing, cubical index and spermathecae).

The overall acceptance rate was $82.46 \%$ and ranged from 81.54 to $83.13 \%$. There were no significant differences between acceptance rates across groups $(\mathrm{P}>0.05)$. This is a similar rate to that reported by Emsen et al. (2003) who noted an acceptance rate of $80 \%$ in one day old larvae and single grafting. Gençer et al. (2000) reported an acceptance rate of $64.5 \%$ in one day old larvae. However, their study is problematic as a comparator with ours as it was conducted across different seasons and they used Apis mellifera anatoliaca, whereas in this study Apis mellifera caucasica were used.

The current study found that queen weight was greater when reared in cell-builder colonies fed on coenzyme Q10 compared to the control group (first graft $214.53 \mathrm{mg}$; second graft $209.49 \mathrm{mg}$ ). Reared queens were classified into three weight classes; heavy queens weighed at least $200 \mathrm{mg}$, medium queens from 190 and $198 \mathrm{mg}$ and light queens $190 \mathrm{mg}$ or less (Kahya et al., 2008). The weight of the first and second graft coenzyme Q10 group were within the heavy group reported by (Kahya et al., 2008).

The length of queens in first grafts in coenzyme Q10 groups was $18.63 \mathrm{~mm}$, and was statistically longer than caffeine, mix, control groups both first and second graft. According to Okuyan and Akyol (2018) the highest correlations between morphometric characteristics of queens is weight and length. Delaney et al. (2011) found that the queen thorax width was positively correlated with the number of sperm found in her spermathecae and mating frequency. The possible explanation is that a larger thorax indicates larger flight muscles allowing longer mating flight duration, and increasing the likelihood of increased mating events. The number of sperm in the spermathecae and the genetic variation of said sperm can be considered a characteristic of overall sperm quality. In our experiment, the mean thorax width in the second graft of coenzyme Q10 and caffeine groups was $4.75 \mathrm{~mm}$ and $4.76 \mathrm{~mm}$ respectively, and these two were statistically wider than control and mix group of second graft. Okuyan and Akyol (2018) demonstrated a positive correlation between queen weight and other morphometric measurements, but in our study the heaviest queen did not necessarily correspond to the widest thorax. Hence, the heaviest group of queen bees were reared from the first graft of coenzyme Q10 group, but the mean thorax width of second graft queens reared from the coenzyme Q10 and caffeine group were statistically wider. In this experiment, the average mean wing length was $10.65 \mathrm{~mm}$, and the means of the second grafts of coenzyme Q10 group was $10.80 \mathrm{~mm}$. The mean wing-lengths were significantly longer than control, caffeine and mix groups. According to Delaney et al. (2011), stored sperm number was positively correlated with wing length. Akyol et al. (2008) indicate that there is a significant correlation between the diameter of spermathecae, quantity of sperm in the spermathecae and brood production. We found that the average diameter of spermathecae of reared queens was $1.13 \mathrm{~mm}$, and this of the second graft coenzyme Q10 group was 1.16 significantly larger than second graft of control, caffeine and mix group.

In this study tested the effects of caffeine and coenzyme Q10 on physical traits of reared queens, and the results demonstrate that cell-builder colonies fed with $200 \mathrm{mg}$ coenzyme Q10 minimum 15 days before graft increase weight, thorax width, and wing length of queens. Heavier queens have better colony acceptance rates, higher mating ratios, earlier onset oviposition, wider spermathecae, storage more sperm in spermathecae, and produce more brood area (Akyol et al., 2008). The queens have wider thorax and longer wing might have mate more drone and store more sperm in spermathecae (Delaney et al., 2011). Thus, queen bees produce worker bees have more genetic diversity, and the colony has better adaptation to different environmental conditions (Calderone et al., 1989; Page and Mitchell, 1990).

Typically, royal jelly is produced by younger bees, and therefore queen larvae are most likely to have been fed by young bees. A possible explanation as to why queens reared on coenzyme Q10 group were heavier is that coenzyme Q10 intake from adult worker bees contains a greater hemolymph protein concentration, increased antioxidant enzyme activity and reduced nosema spp infestation, all of which can increase the production of royal jelly secretion (Strachecka et al., 2014a; Liu, 1990). In this study $5 \mathrm{mg}$ caffeine and $200 \mathrm{mg}$ coenzyme Q10 tested. Whilst we found that coenzyme Q10 increased the quality of reared queens, we did not present these queens to the hive and were unable to determine either the colony queen acceptance rates or brood production of the queens. Consequently, results of this study are unable to confirm that the larger queens reared on the caffeine/coenzyme treatments would necessarily perform better over their lifetime than queens in the control group.

\section{Disclosure}

No potential conflict of interest was reported by the authors.

\section{References}

Aizen M, Harder L. 2009. The Global Stock of Domesticated Honey Bees Is Growing Slower Than Agricultural Demand for Pollination. Current Biology, 19(11): 915-918. doi: 10.1016/j.cub.2009.03.071

Aizen M, Aguiar S, Biesmeijer J, Garibaldi L, Inouye D, Jung C. et al. 2019. Global agricultural productivity is threatened by increasing pollinator dependence without a parallel increase in crop diversification. Global Change Biology, 25(10): 3516-3527. doi: $10.1111 / \mathrm{gcb} .14736$

Akyol E, Yeninar H, Kaftanoglu O. 2008. Live Weight of Queen Honey Bees (Apis Mellifera L.) Predicts Reproductive Characteristics. Journal of The Kansas Entomological Society, 81(2): 92-100. doi: 10.2317/jkes-705.13.1

Amiri E, Strand M, Rueppell O, Tarpy D. 2017. Queen Quality and the Impact of Honey Bee Diseases on Queen Health: Potential for Interactions between Two Major Threats to Colony Health. Insects, 8(2): 48. doi: 10.3390/insects 80200 48 
Archer C, Köhler A, Pirk C, Oosthuizen V, Apostolides Z, Nicolson S. 2014. Antioxidant supplementation can reduce the survival costs of excess amino acid intake in honeybees. Journal of Insect Physiology, 71: 78-86. doi: 10.1016/j. jinsphys.2014.10.006

Ashihara H, Crozier A. 2001. Caffeine: a well-known but little mentioned compound in plant science. Trends in Plant Science, 6(9): 407-413. doi: 10.1016/s1360-1385(01)020556

Bentinger M, Brismar K, Dallner G. 2007. The antioxidant role of coenzyme Q. Mitochondrion, 7: S41-S50. doi: 10.1016/ j.mito.2007.02.006

Brodschneider R, Gray A, Adjlane N, Ballis A, Brusbardis V, Charrière J. et al. 2018. Multi-country loss rates of honey bee colonies during winter 2016/2017 from the COLOSS survey. Journal of Apicultural Research, 57(3): 452-457. doi: 10.10 80/00218839.2018.1460911

Calderone NW, Robinson GE, Page RE. 1989. Genetic structure and division of labor in honeybee societies. Experientia, 45(8): 765-767. https://doi.org/10.1007/bf01974583

De Souza D, Bezzera-Laure M, Francoy T, Gonçalves L. 2013. Experimental evaluation of the reproductive quality of Africanized queen bees (Apis mellifera) on the basis of body weight at emergence. Genetics and Molecular Research, 12(4): 5382-5391. doi: 10.4238/2013.november.7.13

Delaney D, Keller J, Caren J, Tarpy D. 2011. The physical, insemination, and reproductive quality of honey bee queens (Apis mellifera L.). Apidologie, 42(1): 1-13. doi: 10.1051/apido/2010027

Emsen B, Dodologlu A, Gene F. 2003. Effect of Larvae Age and Grafting Method on the Larvae Accepted Rate and Height of Sealed Queen Cell (Apis melliferaL.). Journal of Applied Animal Research, 24(2): 201-206. doi:10.1080/09712119. 2003.9706457

Gençer VH, Qasim Shah S, Firatli Ç. 2000. Effects of Supplemental Feeding of Queen Rearing Colonies and Larval Age on the Acceptance of Grafted Larvae and Queen Traits. Pakistan Journal of Biological Sciences, 3(8): 1319-1322. doi:10.3923/pjbs.2000.1319.1322

Grünewald B. 2010. Is Pollination at Risk? Current Threats to and Conservation of Bees. GAIA - Ecological Perspectives for Science and Society, 19(1): 61-67. https://doi.org/10.14512/ gaia.19.1.13

Kaftanoğlu O, Kumova U, Yeninar H. 1992 “Ana arı yetiştiriciliğinin önemi ve ana arı kalitesini etkileyen faktörler." Doğu Anadolu Bölgesi I. Arıcılık Semineri: 3-4.

Kahya Y, Gençer H V, Woyke J. 2008. Weight at emergence of honey bee (Apis mellifera caucasica) queens and its effect on live weights at the pre- and post-mating periods. Journal of Apicultural Research, 47(2): 118-125. https://doi.org/10. 1080/00218839.2008.11101437
Klein AM, Vaissière BE, Cane JH, Steffan Dewenter I, Cunningham SA, Kremen C, Tscharntke T. 2006. Importance of pollinators in changing landscapes for world crops. Proceedings of the Royal Society B: Biological Sciences, 274(1608): 303-313. https://doi.org/10.1098/rspb.2006.3721

Krol A, Hartwig A, Topolska G. 1992. "Quality of queens reared in colonies receiving sugar supplemented with vitamin B1" Pszczel. Zesz. Nauk, 36: 32-40.

Laidlaw HH, Photographs B. 1979. Contemporary Queen Rearing (Stated First Edition). Dadant Publishers.

Lee C. 2000. Antioxidant ability of caffeine and its metabolites based on the study of oxygen radical absorbing capacity and inhibition of LDL peroxidation. Clinica Chimica Acta, 295(1-2): 141-154. https://doi.org/10.1016/s0009-8981(00) 00201-1

Liu TP. 1990. Ultrastructural analysis on the gland secretion in the extracellular ducts of the hypopharyngeal glands of the honeybee infected by Nosema apis. Tissue and Cell, 22(4): 533-540. https://doi.org/10.1016/0040-8166(90)90081-j

Łopieńska-Biernat Eż, Żółtowska K, Dmitryjuk Mł, Lipiński Z, Szypulska E. 2019. Supplementing With Vitamin C the Diet of Honey Bees Parasitized With Varroa destructor: Effect on Carbohydrate Metabolism. Journal of Agricultural Science, 11(2): 1. https://doi.org/10.5539/jas.v11n2p1

Mahbobi A, Farshineh-Adl M, Woyke J, Abbasi S. 2012. Effects of the Age of Grafted Larvae and the Effects of Supplemental Feeding on Some Morphological Characteristics of Iranian Queen Honey Bees (Apis mellifera meda Skorikov, 1929). Journal of Apicultural Science, 56(1): 93-98. https://doi.org/ 10.2478/v10289-012-0010-1

Morse RA. 1993. Rearing Queen Honey Bees: Second Edition (2nd ed.). Wicwas Press.

Münch D, Amdam GV, Wolschin F. 2008. Ageing in a eusocial insect: molecular and physiological characteristics of life span plasticity in the honey bee. Functional Ecology, 22(3): 407-421. https://doi.org/10.1111/j.1365-2435.2008.01419.x

Okuyan S, Akyol E. 2018. The Effects of Age and Number of Grafted Larvae on Some Physical Characteristics of Queen Bees and Acceptance Rate of Queen Bee Cell. Turkish Journal of Agriculture - Food Science and Technology, 6(11): 1556. https://doi.org/10.24925/turjaf.v6i11.1556-1561.1955

Page RE, Mitchell SD. 1990. Self-Organization and Adaptation in Insect Societies. PSA: Proceedings of the Biennial Meeting of the Philosophy of Science Association, 1990(2): 289-298. https://doi.org/10.1086/psaprocbienmeetp.1990.2.193075

Strachecka A, Krauze M, Olszewski K, Borsuk G, Paleolog J, Merska M, Chobotow J, Bajda, M, Grzywnowicz K. 2014b. Unexpectedly strong effect of caffeine on the vitality of western honeybees (Apis mellifera). Biochemistry (Moscow), 79(11): 1192-1201. https://doi.org/10.1134/ s0006297914110066

Strachecka A, Olszewski K, Paleolog J, Borsuk G, Bajda M, Krauze M, Merska M, Chobotow J. 2014b. Coenzyme Q10 Treatments Influence The Lifespan and Key Biochemical Resistance Systems In The Honeybee,Apis mellifera. Archives of Insect Biochemistry and Physiology, 86(3): 165179. https://doi.org/10.1002/arch.21159 